Cell motility

\section{New jobs for dynein ATPases}

\section{Ian R. Gibbons}

STUDY of the molecular basis of cytoplasmic motile systems requires the use of an appropriate in vitro model. Although various models are available that retain different levels of the in vivo functional and regulatory mechanisms, one of the most useful for studying the elementary properties of a motile system has been direct observation, in the light microscope, of individual protein filaments gliding over the surface of a glass slide coated with the appropriate energy-transducing protein ${ }^{1}$. Study of this phenomenon using purified dynein and brain microtubules is described by Bryce Paschal et al. on page 672 of this issue ${ }^{2}$, as well as by other reports that have appeared during the past two months $^{3-6}$. These data provide the longawaited validation of cytoplasmic dyneins as cytoplasmic motors distinct from the axonemal dyneins of cilia and eukaryotic flagella ${ }^{7}$, and demonstrate that the motile repertoire of dynein is significantly more elaborate than believed hitherto.

The diversity of the numerous microtubule-associated proteins has become highly confusing to the non-specialist. A helpful clarification can be obtained by grouping them into classes and families (see table), analogous to the general scheme proposed for actin-binding proteins in an earlier News and Views article ${ }^{8}$ by Tom Pollard. Because many forms of cytoplasmic microtubules exist in a state of dynamic equilibrium ${ }^{9}$, the study of the skeletal (non-energy-transducing) class of microtubule-associated proteins has generally focused on their ability to copolymerize with tubulin in vitro and to stabilize the resultant tubules. Little is known about their physiological function in the cell.

The members of the energy-transducing class of microtubule-associated proteins are easier to study by virtue of their ATPase activity and of the various in vitro motility models. An abundance of new evidence indicates that most of the complex bidirectional movements of vesicles and organelles that characterize a living cell are driven by one of two molecular motors interacting with a microtubular track. Cytoplasmic microtubules are dynamic, polarized structures, with relatively rapid polymerization of tubulin occurring at their 'plus' end and concurrent slower polymerization or depolymerization at their 'minus' end. In most systems, including nerve axons, the plus end of a microtubule corresponds to its distal end (that further removed from the cell centre) and the minus end to its proximal end, with the same polarities applying also to the more stable tubules of flagellar axonemes. The tubule motor responsible for distally directed vesicle movement in most cells seems to be kinesin, an ATPase that was first isolated from nerve axons and shown to produce both unidirectional movement of latex beads along a microtubule and gliding of microtubules on glass $^{1}$. The motor responsible for proximally directed movement, dynein ATPase, was first characterized from ciliary axonemes as long as 20 years ago, and its structural and enzymatic properties are relatively well known ${ }^{10}$, although as mentioned above, a functionally active form of cytoplasmic dynein was reported only recently ${ }^{3,4}$. The properties of the axonemal dyneins that constitute the 'outer arms' of the microtubules of cilia and sperm flagella are particularly well $\mathrm{known}^{10}$ : a well-defined structure seen in the electron microscope, very large polypeptide subunits of $M_{\mathrm{r}}>400,000$ susceptible to vanadate-mediated photolysis; and high sensitivity of ATPase activity and motility to inhibition by vanadate. The present paper by Paschal et al..$^{2}$ demonstrates that the gliding microtubule procedure can be used to assay the function of outer-arm dynein from sperm flagella, and this provides a basis for probing functional domains of dynein in a manner similar to that successfully exploited with myosin $^{11.12}$. Not surprisingly, the direction of force generated by axonemal dyneins, which has been determined by observations on the sliding disintegration of trypsin-treated cilia, is proximal ${ }^{13}$, the same as that of cytoplasmic dynein from brain ${ }^{4}$.
There remains some uncertainty about the premise of a separate protein motor for each direction of transport along microtubules. Most notably lacking is an explanation for how latex beads coated with a dynein-like protein from the giant amoeba Reticulomyxa can mimic the bidirectional motion of the in vivo vesicular transport on microtubules in reticulopodia of this organism ${ }^{14}$. Nevertheless, the basic premise appears likely to be valid. In flagellar axonemes, where dynein produces sliding between pairs of tubules it does so by forming a structurally stable bond to one tubule and a dynamic crossbridging attachment to the other. In the retrograde transport of cytoplasmic vesicles, the corresponding structural

\begin{tabular}{|c|c|c|c|c|c|}
\hline \multicolumn{6}{|c|}{ Characteristics of microtubule-associated proteins } \\
\hline Class & Family & Source & $\begin{array}{c}\text { Subunit } \\
M_{\mathrm{r}}(\mathrm{K})\end{array}$ & Structure & $\begin{array}{l}\text { In vitro } \\
\text { movement }\end{array}$ \\
\hline \multirow[t]{4}{*}{$\begin{array}{l}\text { Energy- } \\
\text { transducing }\end{array}$} & Dyneins & Cilia/flagella & $>400$ & $\begin{array}{l}2-3 \text { globular ATPase domains } \\
\text { joined by slender stems }\end{array}$ & Proximal \\
\hline & & Brain & $>400$ & & Proximal \\
\hline & $?$ & Reticulomyxa & $>400$ & & Bidirectional \\
\hline & Kinesins & $\begin{array}{l}\text { Brain } \\
\text { Egg }\end{array}$ & $\begin{array}{l}110 \\
134\end{array}$ & $\begin{array}{l}\text { Rod with branches at one end } \\
\text { and small fork at the other }\end{array}$ & $\begin{array}{l}\text { Distal } \\
\text { Distal }\end{array}$ \\
\hline Skeletal & $\begin{array}{l}\text { MAP } 1 \\
\text { MAP } 2 \\
\text { Tau } \\
\text { Tektin }\end{array}$ & $\begin{array}{l}\text { Brain } \\
\text { Brain } \\
\text { Brain } \\
\text { Cilia/flagella }\end{array}$ & $\begin{array}{l}\sim 350 \\
\sim 270 \\
55-62 \\
45-55\end{array}$ & $\begin{array}{l}\text { Thin filament projecting from tubule } \\
\text { Thin filament projecting from tubule } \\
\text { Globular, heterogeneous in size } \\
\text { Similar to intermediate filaments }\end{array}$ & $\begin{array}{l}\text { None } \\
\text { None } \\
\text { None } \\
\text { None }\end{array}$ \\
\hline
\end{tabular}

Microtubule-associated proteins (MAPs) are grouped into classes by their function and subdivided into families according to their physical and enzymatic properties. This grouping is arbitrary and will probably be modified as more data become available. Dynein from brain was formerly called MAP 1C. Subunit $M_{r}$ gives the relative molecular mass of the principal heavy polypeptide subunit; in many cases additional smaller subunits are also present. Right-hand column: 'proximal' indicates movement of an attached structure toward the proximal $(-)$ end of microtubule, corresponding to retrograde axonal transport; 'distal' indicates movement of an attached structure toward the distal $(+)$ end of microtubule, corresponding to anterograde axonal transport.

attachment of the dynein presumably has to be to the membrane of the vesicle, and is possibly mediated by membrane-bound tubulin ${ }^{15}$. Outstanding questions concern the regulation of the motors and how vesicles become attached to the correct motor. Regardless of how the answers to these questions turn out, it is now evident that dynein fulfils a greater variety of jobs in the cytoplasm than has previously been realized.

\footnotetext{
1. Vale, R. D., Reese T. S. \& Sheetz, M. P. Cell 42, 39-50 (1985).

2. Paschal, B. M. et al. Nature 330, 672-674 (1987).

3. Paschal, B. M., Shpetner, H. S. \& Vallee, R. D. J. Cell Biol. 105, 1273-1282 (1987)

4. Paschal, B. M. \& Vallee, R. B. Nature 330, 181-183 (1987) 5. Vale, R. D. \& Toyoshima, Y. Y. J. Cell Biol. 105, 96a (1987) 6. Lye, R. J. et al. Cell 51, 309-318 (1987).

Hyams, J. S. Nature 330, 106 (1987)

8. Pollard T D Nature 312,403 (1984).

9. Mitchison, T. \& Kirschner, M. Nature 312, 237-242 (1984)

0. Johnson, K. A. A. Rev. Biophys. biophys. Chem. 14, 161 $188(1986)$.

11. Harada, Y. et al. Nature 326, 805-808 (1987)

12. Toyoshima, Y. Y., Kron, S. J., McNally, E. M., Niebling, K. R., Toyoshima, C. \& Spudich, J. M. Nature 328, 536539 (1987).

13. Fox, L. A.\& Sale, W. S. J. Cell Biol. 105, 1781-1787 (1987)

14. Euteneuer, U. et al. J. Cell Biol. 105, 125a (1987)

15. Stephens, R. E. Biol. Cell 57, 95-110 (1986)
}

Ian R. Gibbons is at the Pacific Biomedical Research Center, University of Hawaii, Honolulu, Hawaii 926822, USA. 